\title{
KETERSEDIAAN PAKAN KAMBING PADA MUSIM HUJAN DAN KERING DI LOMBOK UTARA, NUSA TENGGARA BARAT, INDONESIA
}

\author{
Availability of Goat Feed in the Rainy and Dry Season in North Lombok, West \\ Nusa Tenggara, Indonesia \\ Dewi Ratih Ayu Daning ${ }^{1)}$, Anjum Martiningsih ${ }^{1)}$ \\ 1) Politeknik Pembangunan Pertanian Malang, Jl. Dr. Cipto 144a, Bedali, Lawang \\ Email: daningstpp@gmail.com \\ Diterima Pasca Revisi: 25 Februari 2021 \\ Layak Diterbitkan: 1 Maret 2021
}

\begin{abstract}
ABSTRAK
Dua survei dilakukan selama musim hujan dan kemarau di Pulau Lombok, Indonesia untuk mempelajari aplikasi pemberian pakan dan pengelolaan kambing yang dipelihara dengan sistem produksi skala kecil. Ditemukan bahwa sejumlah besar hijauan diberikan kepada kambing dengan jenis yang berbeda yang digunakan masing-masing selama musim hujan dan kemarau. Rumput lapang adalah pakan yang paling tersedia dan diberikan kepada kambing sebagai pakan campuran dan satu-satunya. Beberapa hasil samping pertanian seperti padi dan jerami jagung, juga diberikan kepada kambing tetapi dalam jumlah yang lebih kecil. Selanjutnya produksi kambing dijelaskan dengan standar produksi yang baik untuk pengelolaan peternak rakyat.
\end{abstract}

Kata Kunci: Kambing, ketersediaan, hijauan, musim hujan, musim panas

How to Cite:

Daning, D. R. A., \& Martiningsih, A. (2021). Ketersediaan Pakan Kambing pada Musim Hujan dan Kering di Lombok Utara, Nusa Tenggara Barat, Indonesia. Jurnal Nutrisi Ternak Tropis 4 (1) 40-48
*Corresponding author:

Dewi Ratih Ayu Daning

Email: daningstpp@gmail.com

Politeknik Pembangunan Pertanian Malang, Jl. Dr.

Cipto 144a, Bedali, Lawang 


\begin{abstract}
Two surveys were conducted during the wet and dry seasons on Lombok Island, Indonesia to study feeding and management practices for goats raised under the small-scale production system. It was found that a wide range of forages was fed to goats with different types being used during the wet and dry seasons, respectively. Field grasses were the most readily available feeds and these were offered to goats both as a mixed and as the sole diet. Some agricultural byproducts such as rice and corns straw, were also fed to goats but to a lesser extent. Furthermore the goat production were described that on good standard production for smallholder management.
\end{abstract}

Key words: Goats, production system, wet season, dry season, feeding, management, survey

\section{PENDAHULUAN}

Lombok Utara merupakan wilayah yang terbagi menjadi 5 kabupaten dan 33 desa dengan luas wilayah Provinsi Nusa Tenggara Barat 809,53 ha dan jumlah penduduk 245.802 jiwa. Berdasarkan Topografinya, Lombok Utara terbagi dalam kawasan khusus (hutan lindung, kawasan satwa liar, dll) seluas 261,86 ha $(44,30 \%)$ dan sisanya rata-rata lahan pertanian seluas 447,67 dataran rendah $(55,30 \%)$. Luas wilayah perairan Lombok Utara adalah 594,71 ha dengan panjang garis pantai 127 $\mathrm{km}$. Lombok Utara terdiri dari utara di sepanjang bagian tengah terdapat gugusan pegunungan dengan hutan lindung yang berfungsi sebagai hidrologi, sedangkan di sepanjang pantai hanya terdapat dataran yang sempit dan terbatas. Di bagian tengah yang memanjang dari timur ke barat terdapat dataran rendah yang cukup luas yang merupakan kawasan pertanian subur yang memiliki musim hampir sama dengan kotakota lain di Indonesia yaitu musim hujan dan kemarau (BPS, 2009). Pekerjaan utama masyarakat Lombok Utara umumnya bertani dan beternak.

Populasi kambing di Kabupaten Bayan memiliki jumlah tertinggi kedua di Lombok Utara yaitu 13.689 ekor (BPS, 2009). Kambing merupakan salah satu ruminansia terbaik di Lombok Utara karena memiliki keunggulan antara lain mudah dalam pemeliharaan, cepat berkembang biak, dan produksi daging sebagai pengganti daging sapi. Selain itu kambing juga lekat dengan masyarakat Lombok Utara karena merupakan warisan nenek moyang dan budaya yang ada di masyarakat Lombok Utara. Umumnya keluarga peternak memelihara kambing dengan tujuan untuk mendapatkan penghasilan tambahan, jika tanaman yang mereka budidayakan gagal panen, serta tabungan hidup yang bisa dijual kapan saja saat ada kebutuhan finansial yang mendesak.

Pada umumnya peternak kambing di Kecamatan Bayan memberi pakan kambing berupa tanaman yang ada di sela-sela persawahan dan pekarangan belakang. Selain itu peternak juga sering menggembalakan kambing ke sawah dan pegunungan untuk mencari pakan sendiri. Jenis hijauan di Lombok Utara sangat beragam dengan topografi wilayah pegunungan. Namun keanekaragaman jenis pakan ini belum bisa dimanfaatkan secara optimal oleh peternak. Berdasarkan pertimbangan di atas, maka dilakukan survei pakan dan pengelolaan kambing di Pulau Lombok pada musim hujan dan kemarau.

\section{MATERI DAN METODE}

\section{Responden dan lokasi penelitian}

Sebanyak 46 Peternak diwawancarai secara acak dengan kuesioner terencana terutama didasarkan pada sosial ekonomi peternak kambing dan kinerja produktivitas kambing pada musim hujan dan kemarau. Sebanyak 368 ekor kambing yang digunakan sebagai sample di dalam 
penelitian dipelihara dengan sistem pengelolaan peternak rakyat. Sejumlah petani yang memelihara kambing secara intensif, yang dipilih secara acak sebagai responden masing-masing dari daerah basah dan kering di Lombok Utara.

Namun, peternak yang memberi pakan kambing dengan sistem "potong dan angkut" sebagian besar tersebar di daerah basah dan tidak ada perbedaan ekologis yang tegas di ketiga kabupaten ini. Peternak yang memelihara kambing dengan sistem "potong dan angkut" adalah mereka yang tinggal disekitar wilayah produksi tanaman pangan (kebanyakan petani padi). Di sisi lain, peternak yang memelihara kambingnya di lahan kering, dimana kambing merumput pada siang hari dan di kandang pada malam hari. Oleh karena itu, responden dengan sistem perawatan kambing intensif hampir semuanya berada di daerah basah atau di daerah kering yang memiliki sistem produksi tanaman intensif.

\section{Kuesioner dan Wawancara}

Metode yang digunakan adalah purposive sampling dengan minimal responden tiap kecamatan adalah 46. Kuesioner dikembangkan sesuai dengan tujuan penelitian dan dirancang untuk mendapatkan informasi yang akurat dari peternak. Setiap responden diberi penjelasan singkat tentang sifat dan tujuan penelitian dan tanggapannya dicatat langsung pada jadwal survei.

Bagian utama dari studi kuisioner ini adalah tentang karakteristik responden dan karakteristik produksi kambing, aplikasi manajemen dasar, pengetahuan dan dukungan keluarga yang diterima dalam budidaya ternak kambing. Data tentang penampilan reproduksi seperti interval beranak, kelangsungan hidup pedet diperoleh dari peternak melalui pertanyaan yang cermat tentang riwayat reproduksi masa lalu.

\section{Analisis data}

Semua data yang dikumpulkan dimasukkan ke dalam Microsoft Excel 2013 dan statistik deskriptif seperti rerata, frekuensi, persentase digunakan untuk menganalisis data yang diperoleh (Adli dan Sjofjan, 2020).

\section{HASIL DAN PEMBAHASAN \\ Karakteristik social ekonomi dari responden}

Karakteristik umum berhubungan dengan responden skala rumah tangga dibedakan menurut jenis kelamin, umur, status perkawinan, pengalaman memelihara kambing dan status pendidikan disajikan pada Tabel 1 .

Dari total responden yang diwawancarai $(\mathrm{N}=46)$, mayoritas umur (41\%) pada rentang 30-40 tahun, hasil ini menunjukkan bahwa sebagian besar peternak kambing aktif dalam kegiatan beternak kambing. Dilihat dari tingkat pendidikan, responden tertinggi (70\%) pernah SD, 15\% SMP, 4\% SMA, dan 2\% berpendidikan / perguruan tinggi. Selanjutnya untuk status pekerjaan responden menunjukkan bahwa petani pertanian $(89 \%)$ sebagai pekerjaan utama, dan peternak sapi (91\%) sebagai pekerjaan sampingan, tidak diragukan lagi bahwa kedua pekerjaan tersebut merupakan keterkaitan dengan sosial ekonomi petani di desa. Berdasarkan data responden, $75 \%$ petani tidak mendapatkan pelatihan ketrampilan memelihara kambing, sebaliknya $75 \%$ responden memiliki waktu kurang dari 3 tahun untuk beternak kambing, sehingga untuk pengembangan lebih lanjut pemeliharaan kambing diperlukan kerjasama Pemerintah untuk menyelenggarakan pengelolaan praktek kambing untuk petani.

Tujuan pemeliharaan kambing oleh peternak (Tabel 1) diprioritaskan pada hobi (prioritas 1), pendidikan anak (prioritas 2), tabungan (prioritas 3), produksi daging (prioritas 4), limbah (prioritas 5). Berdasarkan data Dahlannudin (2001) menunjukkan bahwa rata-rata jumlah kambing (4.4) yang dimiliki petani di Lombok (Tabel 1) lebih tinggi dari rata-rata nasional yang sebesar 3,5 ekor per petani). Sebagian besar responden $(13,0 \%)$ hanya memelihara satu ekor kambing. 
Tabel 1. Karakteristik social ekonomi responden

\begin{tabular}{|c|c|c|c|}
\hline Parameter & & $\sum$ Peternak & Prosentase $(\%)$ \\
\hline \multicolumn{4}{|c|}{ Umur (tahun) } \\
\hline & $<30$ & 3 & 6 \\
\hline & $31-40$ & 19 & 41 \\
\hline & $41-50$ & 9 & 20 \\
\hline & $>50$ & 15 & 33 \\
\hline \multicolumn{4}{|c|}{ Pendidikan formal } \\
\hline & Tidak sekolah & 4 & 9 \\
\hline & Sekolah Dasar & 32 & 70 \\
\hline & Sekolah Menengah Pertama & 7 & 15 \\
\hline & Sekolah Menengah Atas & 2 & 4 \\
\hline & Universitas S1 & 1 & 2 \\
\hline \multicolumn{4}{|c|}{ Pendidikan non Formal } \\
\hline & Tidak sekolah & 35 & 75 \\
\hline & Kambing & 1 & 2 \\
\hline & Pakan & 6 & 13 \\
\hline & Pupuk & 1 & 2 \\
\hline & Kesehatan ternak & 0 & 0 \\
\hline & Pengolahan & 4 & 8 \\
\hline \multicolumn{4}{|c|}{ Pengalaman memelihara kambing (tahun) } \\
\hline & $<3$ & 31 & 68 \\
\hline & $3-7$ & 8 & 17 \\
\hline & $>8$ & 7 & 15 \\
\hline \multicolumn{4}{|c|}{ Pekerjaan Utama } \\
\hline & Pengangguran & 1 & 2 \\
\hline & Peternak & 1 & 2 \\
\hline & Petani & 41 & 89 \\
\hline & Pedagang & 0 & 0 \\
\hline & Pengusaha & 0 & 0 \\
\hline & Wiraswasta & 2 & 5 \\
\hline & PNS & 1 & 2 \\
\hline \multicolumn{4}{|c|}{ Pekerjaan sampingan } \\
\hline & Pengangguran & 0 & 0 \\
\hline & Peternak & 42 & 91 \\
\hline & Petani & 0 & 0 \\
\hline & Pedagang & 0 & 0 \\
\hline & Pengusaha & 0 & 0 \\
\hline & Wiraswasta & 0 & 0 \\
\hline & PNS & 0 & 0 \\
\hline & Lain-lain & 4 & 9 \\
\hline \multicolumn{4}{|c|}{ Jumlah anggota keluarga (Orang) } \\
\hline & $<3$ & 10 & 22 \\
\hline & $3-5$ & 35 & 76 \\
\hline & $>6$ & 1 & 2 \\
\hline \multicolumn{4}{|c|}{ Tujuan bertani/beternak } \\
\hline & Priority 1 & Hobbi & \\
\hline & Priority 2 & Pendidikan & \\
\hline & Priority 3 & Tabungan & \\
\hline & Priority 4 & Produksi da & \\
\hline & Priority 5 & Limbah & \\
\hline
\end{tabular}


Ukuran flok yang kecil inilah yang menjadi ciri dari peternakan "skala kecil" atau "pekarangan belakang", yang umumnya disebut dalam menggambarkan sistem produksi kambing di Indonesia. Soedjana (1993) mengemukakan bahwa $99 \%$ ruminansia kecil di Indonesia dipelihara oleh peternak kecil.

\section{Deskripsi lahan dan kepemilikan}

Peluang pengembangan kambing di NTB memiliki daya saing yang cukup tinggi, dimana luas lahan kering yang berpotensi untuk pengembangan kambing mencapai $\pm 1,7$ juta Ha. Kambing merupakan hewan pemamah biak yang mampu beradaptasi dengan baik di daerah kering dan iklim, karena dapat memanfaatkan beberapa sumber pakan seperti rumput lapangan, jerami tanaman, dan terutama daun pohon yang disukai kambing (Parkinset al., 1986, Panjaitan dan Tiro, 1996 dan Djayanegara dan Setiadi, 1999). Selanjutnya kondisi lahan termasuk dalam sistem pemeliharaan kambing. Sistem pemeliharaan ekstensif adalah praktik umum di daerah kering pulau (kebanyakan di dataran tinggi di bagian utara pulau), dan di sawah yang terabaikan secara musiman seperti di daerah kering di Lombok utara.

Tabel 2. Deskripsi lokasi dan pemilikan lahan

\begin{tabular}{lcc}
\hline Jenis lahan & Luas $\left(\mathrm{M}^{2}\right)$ & Produksi/panen $(\mathrm{Kg})$ \\
\hline Sawah & & \\
\hline Padi & $1021 \pm 1763$ & $301 \pm 789$ \\
Jagung & $34 \pm 168$ & $6.5 \pm 43$ \\
Lain-lain & $795 \pm 1286$ & 0 \\
\hline Tegalan & & 0 \\
\hline Singkong & 0 & 0 \\
Rumbut & 0 & $3.26 \pm 21.8$ \\
Cabai & $0.43 \pm 2.91$ & $65.21 \pm 437.4$ \\
Lain-lain & $1299 \pm 2128$ & \\
\hline
\end{tabular}

Sebaliknya, sistem pemeliharaan intensif paling banyak di areal produksi tanaman. Berdasarkan observasi data (Tabel 2) sebagian besar petani menanam padi dan jagung di lahan mereka dengan luas ratarata $1021 \mathrm{~m}^{2}$ sehingga limbah pertanian dapat diaplikasikan sebagai pakan kambing. Dari 46 responden adalah petani (89\%) dengan rata-rata $1021 \mathrm{~m}^{2}$ / tiap petani, menurut Kusnadiet al (2005) dijelaskan bahwa Di beberapa desa di Lombok khususnya di kawasan lahan kering usaha tani banyak dilakukan oleh petani.

Dalam 4-6 bulan selanjutnya Berdasarkan observasi data (Tabel 2) Padi dan jagung merupakan komoditas yang paling banyak ditanam di daerah ini. Berdasarkan Kusnadi et al (2005) dijelaskan bahwa hampir semua peternak memelihara kambing dengan skala kepemilikan rendah (1-2 ekor) sebagai bagian dari sistem usahatani.

\section{Deskripsi kepemilikan kambing}

Jumlah rata-rata kambing (5.73) yang dimiliki oleh para petani di Lombok (Tabel 3) lebih tinggi dari rata-rata nasional yang sebesar 3.5 ekor per petani, dilaporkan oleh Suradisastra (1993). Namun, Sutamaet al (1993) melaporkan nilai yang lebih tinggi masing-masing 5,0 dan 6,3 kambing/ peternakan untuk Sumatera dan Jawa. Jumlah rata-rata di Lombok Utara lebih tinggi dari daerah lain karena populasi kambing di Kabupaten Bayan memiliki jumlah tertinggi kedua di Lombok Utara yaitu 13.689 ekor (Badan Pusat Statistik, 2009) dan didukung dengan profil lahan yang dibagian tengah memanjang dari timur. Pada bagian barat terdapat dataran rendah yang cukup luas yang merupakan daerah pertanian yang subur, kepemilikan kambing sangat bervariasi (dari 1 sampai 35 ekor per peternakan). Namun mayoritas responden (lebih dari 52,1\%) memelihara 
kambing kacang, sedangkan yang memelihara kambing silangan hanya 41,3\% dari total responden (Tabel 3). Responden yang cukup banyak $(6,5 \%)$ tidak diketahui ras kambingnya. Ukuran petak kandang yang kecil inilah yang menjadi ciri peternakan "skala kecil" atau "pekarangan belakang", yang secara umum mengacu pada sistem produksi kambing di Indonesia. Soedjana (1993) mengemukakan bahwa 99\% ruminansia kecil di Indonesia dipelihara oleh peternak kecil.

Tabel 3. Deskripsi pemilikan kambing

\begin{tabular}{lcc}
\hline Deskripsi & Jumlah populasi & Persentase $(\%)$ \\
\hline Tidak diketahui & 3 & 6.5 \\
Etawah crossbred & 19 & 41.3 \\
Kambing kacang & 24 & 52.1 \\
Total pupulasi & $5.73 \pm 2.57$ & \\
\hline
\end{tabular}

\section{Deskripsi kebutuhan pakan selama musim hujan dan kemarau}

Jumlah kebutuhan pakan yang tersedia untuk kambing pada musim kemarau (Tabel 4) sangat mirip dengan yang tersedia pada musim hujan, selanjutnya dijelaskan pada Tabel 5 bahwa peternak tidak memiliki penyimpanan pakan sebanyak 56,5\%. Berdasarkan data lahan pertanian Lombok Utara memiliki rata-rata lahan untuk pertanian seluas 447,67 dataran rendah $(55,30 \%)$ (Badan Pusat Statistik Kabupaten Lombok Utara, 2016) sehingga kebutuhan pakan kambing tersedia setiap musim. Dahlanuddin (2001) menjelaskan bahwa Peternak kambing di Lombok yang menggunakan daun pohon seperti yang berasal dari Leucaenaleucocephala dan Gliricidiasepium lebih sering diberi pakan baik sebagai pakan tunggal maupun sebagai pakan campuran selama musim. Demikian pula, lebih banyak produk sampingan pertanian seperti daun ubi jalar, tungku kacang tanah dan daun / brangkasan kacang diumpankan ke kambing selama periode ini. Dalam kondisi tropis, terutama selama musim kemarau, ruminansia diyakini semakin bergantung pada sisa tanaman pertanian yang tersedia berlimpah seperti jerami sereal, yang tinggi serat tetapi rendah protein makanan dan daya cerna. Selanjutnya pada Tabel 6 dijelaskan bahwa hasil samping pertanian digunakan sebagai pakan kambing seperti jerami padi, jerami jagung, jerami kacang tanah oleh 46 responden. Akan tetapi, hasil studi musim kemarau menunjukkan bahwa hanya sedikit peternak yang memberi pakan kambing lokal berkualitas rendah. Berdasarkan hasil observasi mereka hanya menambahkan sedikit pakan komersial pada pakan kambing. Limbah pertanian bisa dijadikan alternative sebagai pakan ternak jika mengalami kendala di musim kemarau (Sjofjan et al., 2020). Bakrie (1996) mengemukakan bahwa "kuantitas hijauan tidak menjadi masalah di Indonesia, itu adalah kualitas pakan yang nampaknya sangat buruk dan suplementasi dianggap perlu".

Fluktuasi pakan musiman merupakan masalah yang sering terjadi pada peternak di daerah tropis. Berdasarkan tabel 4 dijelaskan bahwa pada musim hujan dan kemarau tidak berpengaruh nyata terhadap kebutuhan pakan, namun pada akhir musim kemarau fluktuasi pakan terjadi pada produksi sedang. Di negara tropis, sebagian besar peternak hampir memenuhi kebutuhan pakan dengan sistem potong dan angkut serta konsentrat sebagai sumber pakan alternatif.

Di Lombok Utara pada musim hujan saat penggembalaan over produksi memiliki manajemen pakan untuk penyimpanan hijauan untuk menjaga ketersediaan pakan pada musim kemarau, kondisi tersebut dijelaskan pada tabel 5 bahwa $54 \%$ responden menggunakan limbah pakannya sebagai kompos dan $43,5 \%$ responden memiliki tempat 
penyimpanan pakan di samping kandangnya. Pemanfaatan limbah pakan sebagai kompos sebagian besar diterapkan di petani Lombok yang dimanfaatkan pada lahan pertanian. Karena ketersediaan pakan yang hampir sama pada musim kemarau dan musim hujan, petani tidak takut $56,5 \%$ untuk membangun tempat penyimpanan pakan, sedangkan kambing dipelihara disekitar sawah atau tegalan dari pagi hingga siang hari selama bekerja di lahan pertanian.

Tabel 4. Description kebutuhan pakan selama musim hujan dan kering

\begin{tabular}{|c|c|c|c|c|c|c|}
\hline \multirow[t]{2}{*}{ Kebutuhan pakan } & \multicolumn{3}{|c|}{ Musim hujan } & \multicolumn{3}{|c|}{ Musim kemarau } \\
\hline & Awal & Tengah & Akhir & Awal & Tengah & Akhir \\
\hline Total pakan & 3 & 3 & 2 & 3 & 3 & 2 \\
\hline $\begin{array}{l}\text { Jenis rumput, legume, dan limbah } \\
\text { pertanian }\end{array}$ & 4 & 3 & 2 & 3 & 2 & 2 \\
\hline $\begin{array}{cl}\text { Note: Score } 0-4 & \\
0=\text { tidak ada } & 1=\text { rendah } \\
3=\text { tinggi } & 4=\text { kelebihan pro }\end{array}$ & $\begin{array}{l}=\text { tengal } \\
\text { luksi }\end{array}$ & & & & & \\
\hline
\end{tabular}

Table 5. Deskripsi penggunaan pakan dan limbah

\begin{tabular}{cccc}
\hline Deskripsi & & Total & Persentase $(\%)$ \\
\hline Penggunaan limbah pakan & Yes & 25 & 54.3 \\
& No & 21 & 45.6 \\
\hline Penyimpanan pakan & Yes & 20 & 43.5 \\
& No & 26 & 56.5 \\
\hline
\end{tabular}

Selama musim kemarau kualitas hijauan yang rendah dan limbah pertanian seperti padi dan jerami jagung dapat diolah dengan berbagai metode dan digunakan sebagai sumber pakan alternatif. Data pada tabel 6 menjelaskan bahwa beberapa jenis pakan yang diterapkan dalam pengelolaan pakan kambing antara lain rumput lapang, jerami padi, jerami jagung, jerami kacang tanah, daun pohon legum, rumpun padi, pakan konsentrat, dan ampas tahu.

Periode kemarau yang disebutkan pada studi saat ini pada bulan Juli hingga Oktober terjadi kekurangan pakan kambing pada waktu yang hampir bersamaan berbeda dengan bulan-bulan kemarau yang disebutkan sebelumnya yaitu bulan Juni hingga Oktober (Gamoyo et al., 2015). Hal ini dapat dijelaskan dengan perubahan musim secara bertahap dan kekurangan pakan tidak terjadi secara tiba-tiba, sehingga perlu adanya evaluasi tentang nilai gizi dari hijauan yang tersedia selama masa transisi ini (Adjorlolo et al., 2014). Deskripsi total kebutuhan pakan selama sistem pemeliharaan pada Tabel 6 menjelaskan bahwa peternak hanya bergantung pada jenis pakan dari alam tanpa suplementasi dan hanya sejumlah kecil pakan komersial yang diterapkan pada sistem pakan. Jumlah pakan yang sering digunakan sebagian besar berasal dari rumput lapang yang tersedia di sekitar lahan pertanian.

Berdasarkan penelitian Dahlanuddin (2002) bahwa pada sistem ekstensif, kambing dapat merumput di daerah penggembalaan komunal pada siang hari dan dipelihara di kandang pada malam hari. Sebagai alternatif, kambing dibiarkan merumput dari pagi hingga tengah hari dan kemudian di sore hari. Kambing juga dibiarkan merumput di pinggir jalan dan di sekitar kampung. Dalam kasus terakhir, kambing dipasang tali keluh untuk mencegah mereka memasuki kebun atau sawah. Dalam sistem yang lebih intensif, kambing di kandang atau hanya ditambatkan di halaman belakang sepanjang waktu. Pemberian pakan hijauan dengan cara digantung tatau diletakkan di bak pakan yang menempel pada kandang. 
Performa produksi kambing di Lombok Utara

Rata-rata lama pemeliharaan kambing pada penelitian ini adalah $22,3 \pm 4,93$ bulan dan jumlah kawin ditemukan 1,35 \pm 7,5 dengan pemuliaan alami. Armijo et al (2011) menjelaskan bahwa kambing mencapai seksualitas dewasa pada 4-9 bulan atau rata-rata 8 bulan dan memberikan produktivitas yang maksimal jika dikawinkan pada umur 15-19 bulan, lama kawin selama 150-154 hari dengan frekuensi kelahiran rata-rata 3-4 kali selama 2 tahun.

Table 6. Deskripsi total penggunaan pakan

\begin{tabular}{lccc}
\hline \multicolumn{1}{c}{ Kategori } & $\begin{array}{c}\text { Total } \\
(\mathrm{Kg} / \text { day })\end{array}$ & $\begin{array}{c}\text { Frekuensi pemberian pakan } \\
\text { (kali/hari) }\end{array}$ & $\begin{array}{c}\text { Total pakan } \\
\text { (kg/ekor/hari) }\end{array}$ \\
\hline Rumput lapang & $18.64 \pm 37.5$ & $1.67 \pm 0.95$ & $4.92 \pm 5.17$ \\
Rumput budidaya & $0.56 \pm 2.11$ & $0.17 \pm 0.56$ & $0.304 \pm 1.01$ \\
Jerami padi & $0.521 \pm 0.87$ & $0.25 \pm 0.43$ & $0.521 \pm 0.878$ \\
Jerami jagung & $0.913 \pm 4.38$ & $0.15 \pm 0.35$ & $0.282 \pm 0.68$ \\
Jerami kacang & $3.21 \pm 6.94$ & $0.43 \pm 0.64$ & $1.47 \pm 2.04$ \\
Legume pohon & $3.56 \pm 5.83$ & $0.89 \pm 1.25$ & $1.73 \pm 3.21$ \\
Daun pisang & $0.65 \pm 3.05$ & $0.21 \pm 1.01$ & $0.43 \pm 2.03$ \\
Pakan komersial & $0.05 \pm 0.29$ & $0.06 \pm 0.32$ & $0.01 \pm 0.07$ \\
Dedak padi & $0.13 \pm 0.87$ & $0.043 \pm 0.29$ & $0.01 \pm 0.07$ \\
Ampas tahu & $0.021 \pm 0.14$ & $0.021 \pm 0.14$ & $0.021 \pm 0.14$ \\
\hline
\end{tabular}

Tabel 7. Performa produksi kambing di Lombok Utara

\begin{tabular}{lc}
\hline Parameter & Nilai \\
\hline Durasi pemeliharaan (bulan) & $22.3 \pm 4.93$ \\
Kebuntingan (ekor) & $1.35 \pm 7.5$ \\
Sistem breeding & Kawin alam \\
Service per conception & $0.08 \pm 0.498$ \\
Days open (day) & $0.53 \pm 0.18$ \\
Calving interval (month) & $3.11 \pm 4.72$ \\
Bobot badan (Kg) & $22.5 \pm 5.32$ \\
Lingkar adda (cm) & $43.38 \pm 5.97$ \\
Panjang badan (cm) & $40.03 \pm 9.18$ \\
Tinggi Badan (cm) & $39.66 \pm 8.39$ \\
\hline
\end{tabular}

Dalam penelitian ini keberhasilan pembiakan terutama ditentukan oleh hari buka, semakin lama hari bukan berarti semakin lama jarak beranak yang berpengaruh pada produksi sepanjang umur kambing. Performa reproduksi kambing pada peternak kecil sangat bervariasi, hal ini dimungkinkan banyak faktor yang kurang mendukung dalam pengelolaan pemeliharaan kambing terutama pemenuhan pakan dan kebutuhan lingkungan. Hasil keseluruhan kinerja produksi disajikan pada Tabel 7 yang menjelaskan bahwa rata-rata bobot badan dari 46 peternak adalah $22,5 \pm 5,32 \mathrm{~kg}$ dengan kisaran nilai standar optimum 25-30 $\mathrm{kg}$ untuk kambing kacang.

\section{KESIMPULAN}

Ketersediaan pakan yang ditawarkan kepada kambing di Pulau Lombok pada musim hujan berkisar dari rumput lapang saja, berbagai campuran rumput dengan pakan lain seperti daun pohon, semak belukar atau hasil samping pertanian seperti daun singkong dan kompor kacang tanah atau campuran daun pohon dalam berbagai proporsi. Pakan yang tersedia pada musim kemarau hampir sama dengan pakan pada 
musim hujan. Namun produksi kambing masih menunjukkan performa yang baik di setiap musimnya.

\section{DAFTAR PUSTAKA}

Adjorlolo, L. K., Adogla-Bessa, T., Amaning-Kwarteng, K., \& Ahunu, B. K. (2014). Seasonal effect on rumen function in sheep on range in the Accra Plains of Ghana. Tropical Animal Health and Production, 46(7), 1223-1228. https://doi.org/10.1007/ s11250-014-0629-y

Adli, D. N., \& Sjofjan, O. (2020). Metaanalisis: pengaruh substitusi jagung dengan bahan pakal lokal terhadap kualitas karkas daging broiler. Jurnal Ilmu Peternakan Terapan, 3(2), 4448. https://doi.org/10.25047/jipt.v3i2. 1940

Bakrie, B. (1996). Feeding Management of Ruminant Livestock in Indonesia. Ruminant Nutrition and Production in the Tropics and Subtropics.

BPS. (n.d.). Badan Pusat Statistik Kabupaten Lombok Utara.

Dahlanuddin. (2001). Forages commonly available to goats under farm conditions on Lombok Island, Indonesia. Livestock Research for Rural Development, 13(10).

Devendra, C. (1995). Tropical legumes for small ruminants. In Tropical Legumes in Animal Nutrition (pp. 231-246). CAB International.
Gamoyo, M., Reason, C., \& Obura, D. (2015). Rainfall variability over the East African coast. Theoretical and Applied Climatology, 120(1-2), 311322. https://doi.org/10.1007/s00704014-1171-6

Kusnadi, Dwiyanto, U., \& Bahri, S. (2005). Pengembangan system usaha tani ternak tanaman pangan berbasis kambing di kabupaten Lombok Timur, Nusa Tenggara Barat. Seminar Nasional Teknologi Peternakandan Veteriner, 295-305.

Sjofjan, O., Nur Adli, D., Djunaidi, I., \& Kuncoro, K. (2020). Utilization of biogas liquid waste for starter in the fermentation of rice husk as a potential feed for poultry. Animal Production, 22(1), 24-30. https://doi.org/10.20 884/1.jap.2020.22.1.38

Soedjana, T. D. (1993). Economics of Raising Small Ruminants. In Small Ruminant Production in the Humid Tropics (pp. 336-368). Sebelas Maret University Press.

Suradisastra, K. (1993). Social Aspects of Goat and Sheep Production. In Small Ruminant Production in the Humid Tropics (pp. 336-368). Sebelas Maret University Press.

Vázquez-Armijo, J. F., Rojo, R., Salem, A. Z. M., López, D., Tinoco, J. L., González, A., Pescador, N., \& Domínguez-Vara, I. A. (2011). Trace elements in sheep and goats reproduction: A review. Tropical and Subtropical Agroecosystems, 14(1), 1-13. 